Original Paper

\title{
Pemeriksaan CT-SCAN Thorax Pada Kasus Covid-19 di Provinsi Nusa Tenggara Barat
}

\author{
Novia Andansari Putri Restuningdyah¹, Emmy Amalia ${ }^{*}$ \\ ${ }^{1}$ Fakultas Kedokteran Universitas Mataram, Mataram, Indonesia
}

DOI: $10.29303 /$ jpmpi.v3i1.447

Sitasi: Aini., Kurniawan, E., Permana, Y.R., Halid, I. (2020). Deteksi Dan Pengelolaan Hipertensi Pada Remaja. Jurnal Pengabdian Magister Pendidikan IPA, 3(1). doi: https://doi.org/10.29303/jpmpi.v3i1.447

*Corresponding Author: Emmy Amalia; Fakultas Kedokteran Universitas Mataram, Mataram, Indonesia

Email:

emmy.amalia@ymail.com

\begin{abstract}
Abstrak: Coronavirus disease 2019 (COVID-19) adalah penyakit pernapasan akut yang sangat menular yang disebabkan oleh Severe Acute Respiratory Syndrome Coronavirus-2 (SARS CoV-2) yang merupakan virus pertama kali ditemukan di Kota Wuhan, China pada akhir 2019. COVID-19 telah menyebar dengan cepat secara global, dan pada Maret 2020, telah resmi dinyatakan sebagai pandemi oleh WHO. Salah satu tantangan dalam mengadapi pandemi COVID-19 ini adalah identifikasi modalitas diagnostik yang cepat, mudah diakses, dan terpercaya yang berfungsi sebagai alternatif untuk pemeriksaan RT-PCR yang saat ini masih cukup terbatas jumlahnya dan memerlukan waktu pemeriksaan yang cukup lama. Pemeriksaan CT-scan thoraks adalah pemeriksaan yang utama untuk mengidentifikasi lesi pada paru-paru dan memiliki peran penting dalam mendiagnosis kondisi klinis, pengamatan efek pengobatan, dan evaluasi prognostik penyakit COVID-19. Sehingga pemeriksaan CT-scan thoraks dapat membantu penegakan diagnosis sekaligus mengetahui gambaran CT-scan thoraks pada pasien. Tujuan dari pengabdian ini adalah untuk membantu diagnosis COVID-19 dan mengetahui gambaran pemeriksaan CT-scan thoraks pada pasien-pasien yang dirawat dengan indikasi COVID-19 di Provinsi Nusa Tenggara Barat (NTB), sehingga dapat dilakukan tata laksana lebih tepat terkait kondisi pasien.
\end{abstract}

Kata Kunci: Pemeriksaan; CT-SCAN; Covid-19.

\section{Pendahuluan}

Coronavirus adalah salah satu patogen yang organ targetnya terutama pada sistem perrnapasan (Susilo et al., 2020). Sebelumnya telah terjadi wabah coronavirus yaitu Middle East Respiratory Syndrome Coronavirus (MERS$\mathrm{CoV}$ ) dan Severe Acute Respiratory Syndrome Coronavirus (SARS-CoV) yang secara signifikan menyebabkan ancaman besar bagi manusia (Killerby et al., 2020). Penyakit coronavirus 2019 (COVID-19) didefinisikan sebagai penyakit yang disebabkan oleh coronavirus baru yang sekarang disebut severe acute respiratory syndrome coronavirus 2 (SARS CoV-2) yang sebelumnya disebut 2019-nCoV. Penyakit ini pertama kali diidentifikasi ditengah banyaknya kasus penyakit pernapasan di Kota Wuhan, Provinsi Hubei, China (Susilo et al., 2020). Penyakit ini awalnya dilaporkan ke World Health Organization (WHO) pada 31 Desember 2019. Kemudian pada 30 januari 2020, WHO menyatakan COVID-19 sebagai wabah kedaruratan kesehatan secara global. Tidak sampai satu bulan, penyakit ini telah menyebar di berbagai provinsi lain di China, 
Thailand, Jepang dan Korea Selatan. Pada 11 Maret 2020, WHO menyatakan COVID-19 sebagai pandemi global (Susilo et al., 2020)(Cennimo, 2020).

COVID-19 pertama kali ditemukan berupa empat kasus serupa yang diidentifikasi berasal dari orang-orang yang memiliki kontak dengan pasar makanan laut lokal di Kota Wuhan, China. Kemudian ditemukan bahwa penularan COVID-19 sebagai infeksi sekunder yaitu dengan penularan antar manusia itu sendiri meskipun tanpa adanya riwayat paparan dengan hewan yang menjadi sumber penularan COVID-19 atau riwayat mengunjungi Kota Wuhan. COVID-19 ini memiliki tingkat penularan yang tinggi sehingga salah satu tantangan dalam mengadapi penyakit ini adalah identifikasi modalitas diagnostik yang cepat mudah diakses, dan terpercaya yang berfungsi sebagai alternatif untuk pemeriksaan RT-PCR yang relatif membutuhkan waktu, terutama di Provinsi NTB. COVID-19 dapat menyebabkan lesi inflamasi pada paru-paru yang disebut dengan pneumonia novel coronavirus. Pemeriksaan CT-scan thoraks adalah pemeriksaan yang utama untuk mengidentifikasi lesi pada paru-paru dan memiliki peran penting dalam mendiagnosis klinis, pengamatan efek pengobatan, dan evaluasi prognostik penyakit COVID-19. Sehingga dilakukannya pemeriksaan CT-scan thoraks dapat membantu penegakan diagnosis COVID-19 serta memberi gambaran CT-scan pada pasien-pasien COVID-19. Berangkat dari latar belakang tersebut, tim pengmas melakukan CT-scan pada pasien-pasien dengan indikasi COVID-19 di dua rumah sakit di NTB, yaitu di RSUD Provinsi NTB dan RS Harapan Keluarga.

\section{Metode Pelaksanaan}

Kegiatan ini diselenggarakan dengan melakukan pemeriksaan CT Scan thoraks pada tenaga kesehatan di RSUD Provinsi Nusa Tenggara Barat dan RS Harapan Keluarga.
Adapun tahapan kegiatan ini dimulai registrasi pasien, kemudiian dilanjutkan dengan persiapan alat dan bahan pemeriksaan kemudian persiapan pasien : pasien diminta untuk melepaskan pakaian dan aksesoris yang dikenakan kemudian menggunakan baju pemeriksaan dan masuk ke dalam Chamber. Setelah itu dilakukan pemeriksaan radiologis, kemudian mencetak hasil pemeriksaan yang dilanjutkan dengan mengevaluasi dan melaporkan hasil temuan pada pemeriksaan radiologis. Personalia kegiatan ini dipaparkan pada Tabel 1.

Tabel 1. Personalia Kegiatan Pengabdian

\begin{tabular}{cll}
\hline No & Nama dosen & \multicolumn{1}{c}{ Deskripsi Tugas } \\
\hline 1 & Dr. Novia & - Penyusunan proposal \\
& Andansari Putri, & - Melaksanakan dan \\
& Sp.Rad & menilai hasil CT-scan \\
& thoraks \\
& & - Penyusunan laporan \\
& & kegiatan \\
& & - Penyusunan proposal \\
& Dr. Emmy & kegiatan \\
& Amalia, Sp.KJ & - Rekam administratif \\
& & hasil kegiatan \\
& & - Membantu penyusunan \\
& & laporan kegiatan \\
\hline
\end{tabular}

\section{Hasil dan Pembahasan}

Sebanyak 50 orang pasien dengan indikasi COVID-19 (terdapat gejala gangguan sistem pernafasan, demam, riwayat pulang bepergian dari zona merah atau terdapat riwayat kontak dengan pasien + COVID-19) yang dirawat di RSUD Provinsi NTB dan RS Harapan Keluarga dilakukan CT Scan thoraks untuk menilai gambaran paru yang dicurigai menderita pneumonia pada Covid 19.

Pada awalnya pada pasien dilakukan foto thoraks (konvensional radiologi) sebagai salah satu pemeriksaan penunjang wajib, kemudian dilakukan dengan pemeriksaan CT scan thoraks. Dari hasil CT-scan 50 orang pasien, terdapat 23 pasien dengan gambaran paru sebagai berikut:

1. Terdapat gambaran bilateral peripheral ground glass opacity

2. Terdapat gambaran crazy paving patten 
dimana kedua gambaran ini menunjang untuk dikategorikan probable COVID-19 (kemungkinan besar menderita). Sementara 27 orang pasien sisanya mempunyai gambaran CT-scan normal.

Dari 23 orang pasien dengan probable COVID-19 tersebut, selanjutnya didapatkan sebanyak 20 orang pasien mempunyai hasil swab PCR positif atau biasa disebut confirmed case.

COVID-19 diumumkan sebagai wabah pandemi di seluruh dunia oleh WHO sejak 11 Maret 2020 maka dari itu deteksi dini COVID19 sekarang menjadi tugas penting bagi para praktisi klinis. Seluruh warga terutama tenaga medis yang menangani pasien perlu tetap waspada untuk mencegah terjadinya transmisi manusia ke manusia terutama penularan nosokomial yang memegang peranan penting dalam mengurangi penyebaran penyakit ini. Hal ini menjadi prioritas utama mengetahui orang yang terinfeksi sehingga prosedur pencegahan dapat diproses untuk meminimalkan penyebaran COVID- 19 dan untuk memulai perawatan kesehatan medis awal terhadap mereka yang terinfeksi, khususnya bagi tenaga kesehatan yang memiliki risiko tinggi kontak dengan pasien yang terkonfirmasi. Oleh karena itu, tim radiologi diharapkan dapat menyadari semua tindakan pencegahan dan strategi untuk membantu meminimalkan risiko infeksi antara tenaga kesehatan dengan pasien.

Pemeriksaan radiologis dapat dipertimbangkan untuk dilakukan, terutama saat pasien pertama kali datang memeriksakan diri sehingga memudahkan penilaian penyakit pada awal dan tahap lanjut. Standar pemeriksaan dari COVID-19 adalah Real-Time Reverse Transcriptase Polimerase Chain Reaction (RT-PCR), namun pemeriksaan CT scan juga direkomendasikan sebagai pemeriksaan utama untuk mendiagnosis COVID-19 di provensi Hubei, Cina. Hasil RT-PCR seringkali menimbulkan error pada sampling dan low virus load. Selain itu RT-PCR lebih sulit dijangkau dan sulit dilakukan. Beberapa kasus melaporkan adanya hasil CT Scan menggambarkan gambaran pneumonia namun dilakukan pemeriksaan RT-PCR berkali-kali dan hasilnya negatif. Penelitian dari Fang, et.al untuk membandingkan tingkat deteksi dari CT Scan dan RT-PCR, hasilnya ditemukan deteksi dengan CT Scan lebih tinggi dibandingkan RT-PCR pertama. Oleh karena itu alat skrining COVID-19 dengan pemeriksaan CT Scan dapat membantu deteksi dini penyakit ini lebih cepat dibandingkan menunggu hasil RT-PCR. Dari segi sensitivitas, rontgen thoraks berada di bawah pemeriksaan CT-scan thoraks. COVID-19 umumnya akan menyebabkan pneumonia viral dengan berbagai tingkat keparahan, pemeriksaan dengan CT Scan dapat mendeteksi tingkat keparahan penyakit dibandingkan pemeriksaan radiologi lainnya seperti foto polos thoraks.

Berbagai cara diagnosis medis COVID19 dapat dilakukan untuk mendeteksi kasus COVID-19. Cara diagnosis medis COVID-19 ini mencakup karakteristik klinis dan diagnosis radiologis. Diagnosis ahli radiologi melibatkan pemindaian computed tomography (CT) dan rontgen toraks (X-ray) apabila CT Scan tidak tersedia. Gejala COVID19 dapat dideteksi secara efektif menggunakan gambar CT scan dengan gambaran mirip pneumonia. Berdasarkan CT scan ahli radiologi dapat mendeteksi pneumonia (COVID-19) dan mengevaluasi tahap pemulihan atau pemburukan pasien.

Berdasarkan studi mendalam umumnya CT-scan thoraks direkomendasikan untuk deteksi pasien yang terinfeksi COVID-19. CT scan sebagai suatu marker untuk mendeteksi gambaran kelainan paru pada kasus COVID19, dapat digunakan sejak awal pasien dengan indikasi COVID-19 datang ke rumah sakit. Cara ini juga akan bermanfaat bagi tim kesehatan yang nertugas sehingga mereka dapat melakukan perlindungan diri yang tepat sejak awal. Cara ini juga dapat digunakan untuk mendeteksi tenaga kesehatan di RSUD Provinsi Nusa Tenggara Barat yang memiliki risiko tinggi terpapar/terinfeksi COVID-19. Temuan pada CT-scan thoraks secara 
umumnya lebih jelas terlihat dibandingkan https://doi.org/10.7454/jpdi.v7i1.415

foto thoraks. Temuan yang dapat ditemukan pada kedua pemeriksaan tersebut yaitu temuan ground glass opacity (GGO) dan/atau konsolidasi secara bilateral baik fokal maupun multifocal terutama dengan distribusi di perifer atau posterior/lobus bawah paru

\section{Kesimpulan}

Pada kegiatan ini telah dilakukan pemeriksaan CT-scan thoraks pada pasien dengan gejala infeksi sistem pernapasan yang dicurigai menderita pneumonia pada infeksi Covid 19 di RSUD Provinsi NTB dan RS Harapan Keluarga, kemudian dilakukan pemeriksaan Swab PCR. Dari 50 pasien yang dilakukan CT-scan thoraks, 23 orang dinyatakan probable COVID-19. Dari 23 orang pasien dengan probable COVID-19 ini, selanjutnya didapatkan hasil swab positif (confirmed case). Berdasarkan hasil tersebut, dapat dikatakan bahwa pemeriksaan CT-scan thoraks dapat digunakan sebagai penujang diagnostik yang cukup sensitif dalam membantu penegakan diagnosis pneumonia pada infeksi COVID 19.

\section{Daftar Pustaka}

Cennimo, D. J. (2020). Coronavirus Disease 2019 (COVID-19). Medscape Medical New, 1-35. Retrieved from https://emedicine.medscape.com/article /2500114-overview

Killerby, M. E., Biggs, H. M., Midgley, C. M., Gerber, S. I., \& Watson, J. T. (2020). Middle East Respiratory Syndrome Coronavirus (MERS-CoV). The Indonesian Journal of Infectious Disease, 26(2), 191-198. https://doi.org/10.3201/eid2602.190697

Susilo, A., Rumende, C. M., Pitoyo, C. W., Santoso, W. D., Yulianti, M., Herikurniawan, H., ... Yunihastuti, E. (2020). Coronavirus Disease 2019: Tinjauan Literatur Terkini. Jurnal Penyakit Dalam Indonesia, 7(1), 45. 